\title{
Shift of the western boundary of the distribution area of Micromeria cristata (Hampe) Griseb. and Steptorhamphus tuberosus (Jacq.) Grossh.
}

\author{
Danka Petrović* $*$ DaniJela SteŠEvić \\ Biology Deptartment, Faculty of Natural Sciences and Mathematics, \\ University of Montenegro, Džordža Vašingtona bb, 81000 Podgorica, Montenegro
}

\begin{abstract}
During field investigations of Mt Rumija, two new taxa for the flora of Montenegro were recorded: Micromeria cristata (Hampe) Griseb. and Steptorhamphus tuberosus (Jacq.) Grossh. From the phytogeographic point of view these data indicate a change in the distribution area of both taxa, which have shifted to the west. A short overview of the taxonomic treatment of both genera is given.
\end{abstract}

Key words: flora, Montenegro, Mt Rumija, Micromeria cristata, Steptorhamphus tuberosus

\section{Introduction}

Rumija is the southernmost part of the Dinaric Alps, the Adriatic coastal mountain chain, extending in a NW-SE direction, situated between Skadar Lake and the Adriatic Sea. Part of the mountain lies in Albanian territory, and can be considered as both a geographic and a phytogeographic link between the Albanian, Macedonian and Greek mountains. Several taxa reach the limits of their distribution area on Mt Rumija: Valeriana dioscoridis Sibth. et Sm. and Ramondia serbica Panč. are the easternmost limit (HAYEK 1931, Stevanović and Bulić 1992), Cionura erecta (L.) Griseb. and Gymnospermium altaicum ssp. scipetarum (E. Mayer et Pulević) Kit Tan et Mullaj are the westernmost (BLEČIĆ and Pulević 1979, Tan and Mullaj 2001) and Centaurea incompta Vis. is the southwestern (HAYEK 1931). Mt Rumija, accordingly, can be characterised as a kind of a floristic crossroad between the western and eastern Balkans.

On Mt Rumija the following parts are clearly distinguished: a) a longitudinal ridge with its high summits- the summit of Rumija, (1593 m),Vrsuta (1184 m) and Lonac (1179 m); b) numerous cliffs, ravines, defiles, karst valleys, sharp peaks- in this area the hill called Vladimir (486 m) is situated; c) the mountain of Lisinj $(1351 \mathrm{~m})$, which rises in the south-west. Southern slopes up to 300-400 m are exposed to the Mediterranean climate,

* Corresponding author, email: danka.petrovic@t-com.me

Copyright $^{\circledR} 2011$ by Acta Botanica Croatica, the Faculty of Science, University of Zagreb. All rights reserved. 
while the northern and higher altitude southern slopes are affected by a modified Mediterranean or sub Mediterranean per humid variant of climate. The geological substrate is polymorphic: flysch is dominant on southern and chalk on northern slopes (MILANOVIĆ 1964).

Such specific geographic position, climate and geology are reflected in the development of a very interesting plant-life that has attracted attention of botanists since the second half of the $18^{\text {th }}$ century. Although numerous publications (e.g. EBEL 1844; BALDACCI 1891, 1892, 1894, 1900, 1901; PANČIĆ 1875; ADAMOVIĆ 1913; RoHLENA 1942; ČERNJAVSKI et al. 1949; PULEVIĆ 2005) have provided data about the flora of this area, it is still incompletely known.

A summary of all the literature data (only the most important contributions are listed in the paragraph above) and of our own field investigations, which began in early spring 2000, the checklist of vascular flora of Mt Rumija consists of more than 1500 taxa (excluding the psamophilic and halophilic vegetation of the coastal part of the mountain). During the field investigations several species that are new for the Montenegrin flora were recorded (PETROvić 2005). In this paper we will present Micromeria cristata (Lamiaceae) and Steptorhamphus tuberosus (Cichoriaceae the westernmost limits of the distribution area of which are on Mt Rumija. In addition we will give a short overview of the taxonomic treatment of both genera.

\section{Material and methods}

Material was collected during field investigations of Mt Rumija, conducted in mid-summer 2006 (Micromeria cristata (Hampe) Griseb) and late spring 2007 (Steptorhamphus tuberosus (Jacq.) Grossh.). It is preserved in the herbarium collection of the Faculty of Natural Sciences in Podgorica, voucher numbers: 968/06 and 642/07. Identification of Steptorhamphus was conducted according to FERÁKOVA (1976, 1977) and DAVIS (1982), while nomenclature follows FERÁKOVA (1977). Identification of Micromeria was conducted according to DiKLIĆ (1974), ŠIlić (1979), BALL and GETLIFFE (1972) and nomenclature according to BRÄUCHLER et al. (2008). Material is also compared with herbarium specimens preserved in the herbarium collection of the Institute of Plant Sciences in Graz. Due to the diverse taxonomic treatments of Micromeria and Steptorhamphus genera a short taxonomic overview is given (BALL and GETLIFFE 1972; CHATER and GUINEA 1972; ŠILIĆ 1979; DAVIs 1982; Greuter et al. 1986; WAgSTAFF et al. 1995; PrATHER et al. 2002; Trusty et al. 2004; BrÄUCHLER et al. 2005; KoOPMAN et al. 1998; STEBBINS 1937; TuISL 1968; FerÁKOVA 1977; KILIJAN 2001; LEBEDA et al. 2001, 2004). In order to avoid confusion with similar plants in our flora, some important morphometric features are specified, such as length of the flower and verticillaster peduncle (Micromeria) and the presence of an outer minute pappus row (Steptorhamphus).

IUCN characterization is in accordance with the most recent Guidelines for Using the IUCN Red List Categories and Criteria (ANONYMOus 2010), while the regional justification of categories follows the Guidelines for Application of IUCN Criteria at Regional Levels (ANONYMOUS 2003). Sources of threats and recommendation measures are defined due to the Authority Files, prepared by IUCN, Major Threats Authority File and Conservation Actions Authority File (http://www.iucn.org). From the time of the first record, the species was monitored up to September 2010 at a frequency of several times a year. Only mature individuals were counted. 


\section{Results}

During the field investigations of Mt Rumija two new taxa for the flora of Montenegro were recorded: Micromeria cristata (Hampe) Griseb. subsp. cristata and Steptorhamphus tuberosus (Jacq.) Grossh. The first taxon was collected in Seoca village, northern slopes, N $42^{\circ} 13^{\prime}$ 83" E 19० 08' 27", altitude ca $250 \mathrm{~m}$, in rock crevices in the Stipo-Salvietum officinalis H-ić (1956) 1958 association, developed as a degradation stage of white hornbeam shrubland (Rusco-Carpinetum orientalis Blečić et Lakušić 1966.) and representing the most common type of rocky pastures in the southern part of the country. The population has fewer than 50 individuals. They share a habitat with the related Micromeria juliana (L.) Bentham. Although very similar in habitus and ecology, these species can be clearly distinguished by the length of the flower and verticillaster peduncle (Fig 1). Micromeria cristata flowers are distinctly pedicellate and verticillasters are pedunculate, in distinction to $M$. juliana, which has sessile flowers and subsessile verticillaster. However, we suspected there was a possibility of confusion as result of which in previous surveys $M$. cristata might have been overlooked in rich populations of M. juliana. After the first record in 2006, no new populations of this species have been found in similar habitat types in the sub-Mediterranean part of Montenegro.

The first records of Steptorhamphus tuberosus (Fig. 2) date from 2007. The species was collected in the vicinity of the village of Godinje (northern slopes of Rumija mountain, $\mathrm{N}$ $42^{\circ} 13^{\prime} 52^{\prime \prime}$, E $19^{\circ} 06^{\prime} 32^{\prime \prime}$, altitude $86 \mathrm{~m}$ ), in the plant community Carpinetum orientalis punicosum O. Greb 1949., one of the degradation stages of white hornbeam forests and

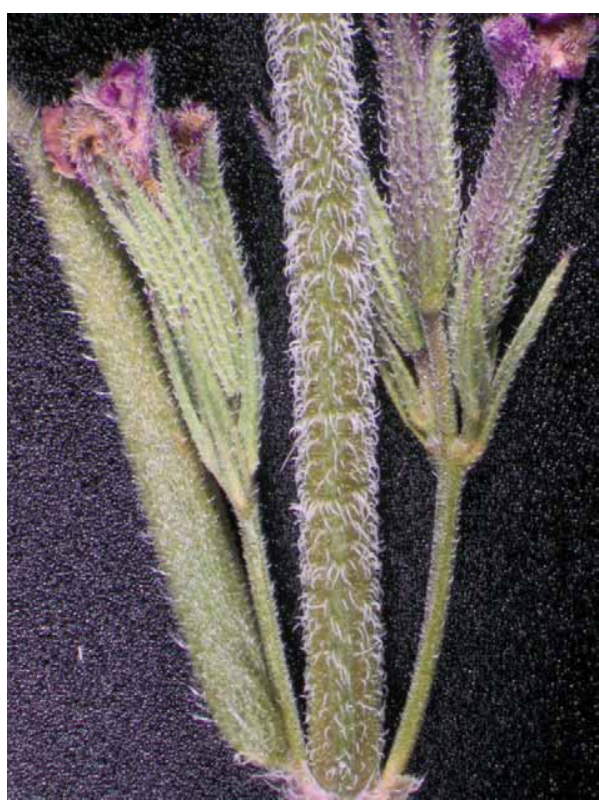

Fig 1. Micromeria cristata, verticillasters (photo by D. Petrović)

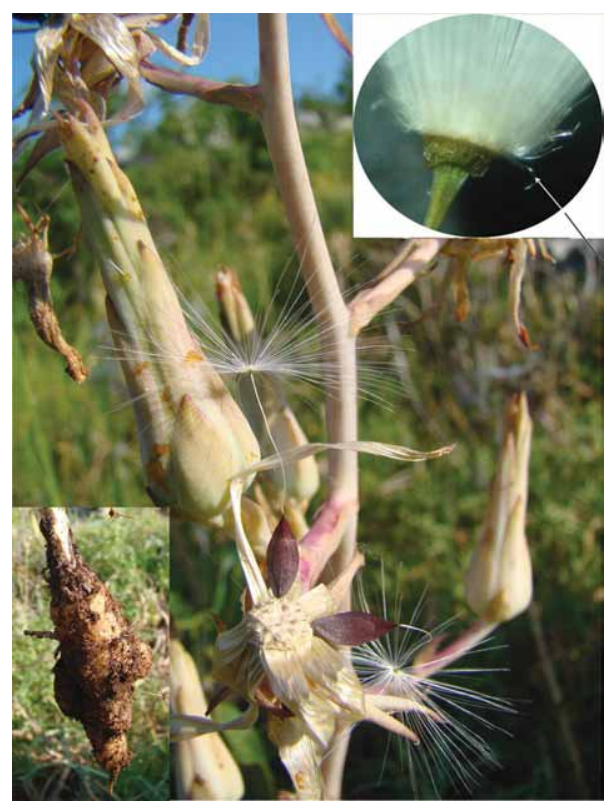

Fig. 2. Steptorhamphus tuberosus, a) inflorescens, $b$ ) root, and c) pappus (photo by D. Petrović) 
shrublands. The population consisted of approximately 30 individuals and it has remained stable. Another population of $S$. tuberosus has been found on the southern slopes of Rumija mountain (Spilica, N 42 05' 50", E $19^{\circ} 08^{\prime} 37^{\prime \prime}$, altitude $195 \mathrm{~m}$ ). It inhabits a site similar to that of the previous population- a fringe of Rusco-Carpinetum orientalis Blečić et Lakušić 1966., a degradation stage of white hornbeam shrubland. Population size is much smaller (fewer than 10 individuals) and has remained stable.

\section{Discussion}

\section{Taxonomic position of Micromeria cristata (Hampe) Griseb.}

According to some taxonomists, the genus Micromeria Benth. is considered a part of the »Satureja complex«, which is, due to morphological diversity, divided into several genera: Satureja L., Calamintha Mill., Clinopodium L., Acinos Mill., Micromeria Benth. (BAll et Getliffe 1972, Davis 1982, ŠIlić 1979). According to others, it is included in the genus Satureja L. (GREUTER et al. 1986). Recently conducted studies of the phylogeny and generic status of Satureja s.l. (WAGSTAFF et al. 1995, PRATHER et al. 2002, TRUSTY et al. 2004, BRÄUCHLER et al. 2005) clearly show that the genus is not monophyletic.

The genus Micromeria includes about 54 accepted species with 32 subspecies and 13 varieties BRÄUCHLER et al. (2008). Following this taxonomic approach and revising Rohlena (1942), ŠILIĆ (1979) and PulEVIĆ (2005) we found that in the Montenegrin flora Micromeria is represented by 5 species: Micromeria graeca (L.) Benth. ex Rchnb., Micromeria croatica (Pers.) Schott., M. juliana (L.) Benth. ex Rchnb., M. longipedunculata Bräuchler and M. kerneri Murb. During field investigations of Mt Rumija an additional Micromeria species was recorded $-M$. cristata, which is according to BRÄUCHLER et al. (2008) subdivided into 6 subspecies: M. cristata subsp. carminea (P. H. Davis) P. H. Davis, M. cristata (Hampe) Griseb. subsp. cristata, M. cristata subsp. kosaninii (Šilić) Bräuchler et Govaerts, M. cristata subsp. orientalis P. H. Davis, M. cristata subsp. phrygia P. H. Davis, M. cristata subsp. xylorrhiza (Boiss. et Heldr. ex Benth.) P. H. Davis. Data on general distribution (GREUTER et al. 1986, DAVIS 1982, HAND 2006 and JAMZAD 2009) show that four subspecies are endemic to Anatolia, while the type species and M. cristata subsp. kosaninii are distributed in the Balkan Peninsula. In the flora of Montenegro only the subspecies cristata exists.

\section{Geographic distribution of Micromeria cristata}

The main part of the distribution area occurs on the Balkan peninsula, in Albania, Bulgaria, Greece, Serbia, Kosovo, Macedonia (ŠILIĆ 1979) (Fig. 3), but the species is also reported for Anatolia (DAVIS 1982) and Iran (JAMZAD 2009). Thus the new finding of Micromeria cristata on Mt Rumija means a shift of the limit of its distribution area towards the west.

\section{Endangered status and protection}

During the field survey we estimated that the population of Micromeria cristata in Montenegro consists of fewer than 50 mature individuals. Due to this fact, and according to criterion D1, the IUCN threat category is CR (Critically endangered) (ANONYMOUS 2010). But, taking into account the possibility of immigration from the neighbouring area (Albania in the first place), the regional Red List Category (ANONYMous 2003) should be 


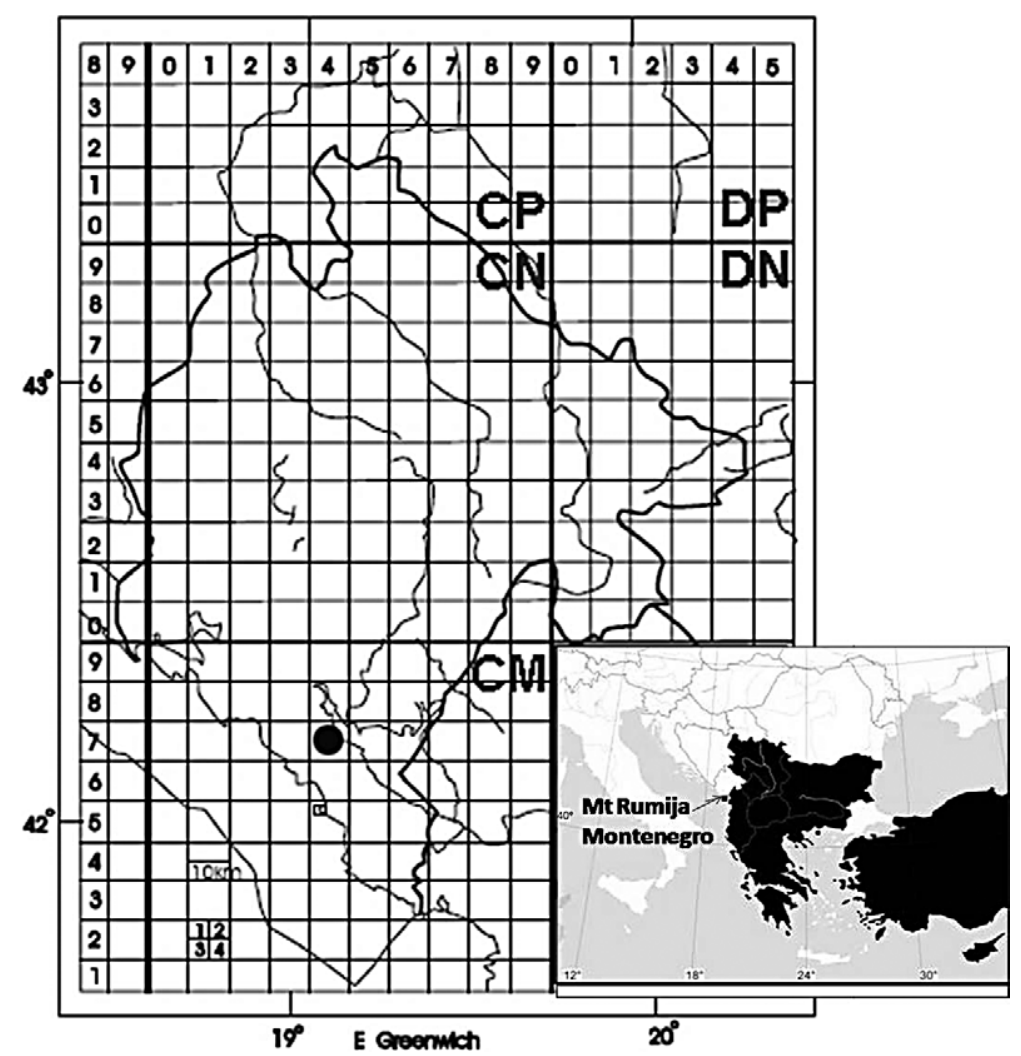

Fig. 3. UTM map of Montenegro (source: Geokarta's UTM basemap) with the record of Micormeria cristata on Mt Rumija, and general distribution map of $M$. cristata (with permission from Atlas Florae Europaeae).

changed to EN (Endangered). Monitoring conducted in the period 2006-2010 showed that the population is stable. However, even a small environmental change could seriously endanger this species.

\section{Taxonomic position of Steptorhamphus tuberosus (Jacq.) Grossh.}

Similar to that of Micromeria, the taxonomic position of the genus Lactuca s. 1. is not simple. There are 3 basic concept of the genus given by Stebbins, Tuisl and Feráková (KoOPMAN et al., 1998). According to StebBins (1937), the genus Lactuca s. 1. also includes the following genera Mulgedium Cass., Lactucopsis Schultz-Bip. ex Vis. Et Panc., Phaenixopus Cass, Mycelis Cass. and part of Cicerbita. TuISL (1968) gave a stricter concept of the genus and singled out Mulgedium, Scariola FW. Schmidt (= Phaenixopus), Cicerbita, Cephalorrhynchus Boiss. and Steptorhamphus. Clasification by FERÁKOVA $(1976,1977)$ is intermediate so the genera Mulgedium, Lactucopsis and Phaenixopus/Scariola are included in genus Lactuca, while Mycelis, Cicerbita, Cephalorrhynchus and Steptorhamphus are not. The presence of an outer minute pappus row (Fig. 2) was the main feature used by Ferákova to keep this genus separate from Lactuca. 
Flora Europaea follows Ferakova's concept where Lactuca cretica Desf. contains two unequal rows of hairs, and is transferred to the genus Steptorhamphus (S. tuberosus (Jacq.) Grossh.). Molecular analysis based on ITS-1 DNA sequences (KoOPMAN et al. 1998), has not supported a distinction between Lactuca and Steptorhamphus. Nevertheless, these investigations were not sufficient for a revised delimitation of Lactuca and related genera (KILIJAN 2001). Despite this, GReuter et al. (2008) included the genus Steptorhamphus into Lactuca. In the recent publications on the distribution and ecology of Lactuca species in Europe (LEBEDA et al. 2001, LEBEDA et al., 2004), the taxon L. tuberosa Jacq. is not treated within this genera.

In our paper we decided to follow the concept of the monographer (FERAKOVA 1977), arguing that molecular analysis still has not resolved the »Lacuca-Steptorhamphus « taxonomical problem.

\section{Geographic distribution of Steptorhamphus tuberosus}

Only a part of the Steptorhamphus tuberosus distribution area occurs in the southern and eastern part of the Balkan peninsula (Fig. 4). An interesting detail is that in spite of a

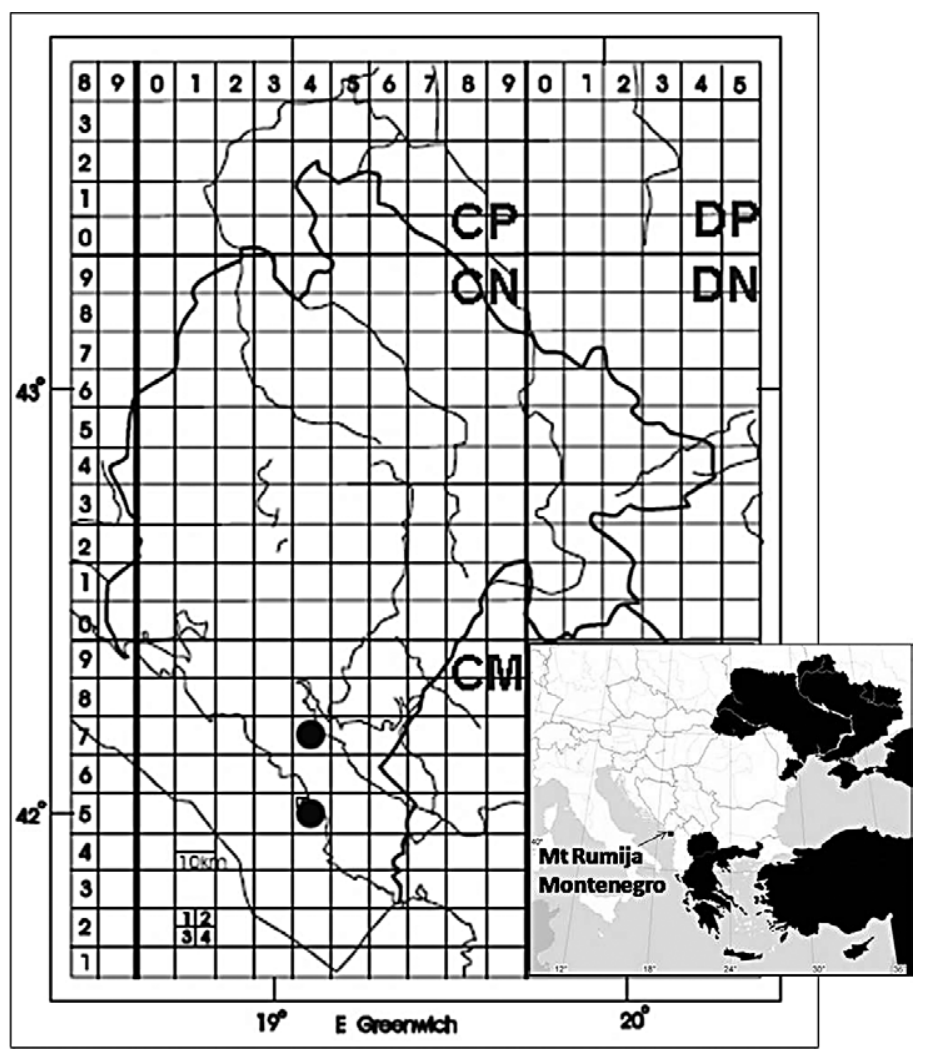

Fig. 4. UTM map of Montenegro (orig., map, source: Geokarta's UTM basemap) with the record of Streptorhaphus tuberosus on Mt Rumija, and general distribution map of S. tuberosus (with permission from Atlas Florae Europaeae). 
previous record of this taxon in Macedonia (SOŠKA 1939, BORNMÜLLER 1926), Flora Europaea did not include ex-Yugoslavia in its geographic distribution. Just as in the case of Micromeria cristata, a new record of the species on Mt Rumija (Montenegro) means a moving of the limit of its distribution area towards the west.

\section{Endangered status and protection}

During the field survey we estimated that the population of Steptorhamphus tuberosus in the village of Godinje consists of approximately 30 mature individuals, while on the southern slopes only a few (less than 10) have been counted. Due to this fact, and according to criteria D1, the IUCN category of threat is CR (Critically endangered) (ANONYMOUS 2010). Since the species is not recorded in neighbouring countries, the regional Red List Category need not to be changed. Monitoring of Steptorhamphus tuberosus population during the period 2007-2010 showed that the population is stable.

\section{Acknowledgements}

We are grateful to our colleague Bojan Zlatković for valuable help with the literature and the editors of Atlas Florae Europaeae Arto Kurtto et al. for permission to use the copyrighted AFE basemap.

\section{References}

AdAmović, 1913: Contribution to the knowledge of flora of the Kingdom of Montenegro (in Serbian). Rad JAZU 195 1-96.

ANONYMOUS, 2003: Guidelines for application of IUCN red list criteria at regional levels: Version 3.0. IUCN Species Survival Commission. IUCN, Gland, Switzerland and Cambridge, UK.

ANONYMOUS, 2010: IUCN standards and petitions subcommittee. 2010. Guidelines for using the IUCN red list categories and criteria, Version 8.1. Prepared by the Standards and Petitions Subcommittee in March 2010. Downloadable from http://intranet.iucn.org/ webfiles/doc/SSC/RedList/RedListGuidelines.pdf.

Ball, P. W., Getliffe, F. M., 1972: Satureja L., Acinos Miller, Clinopodium L., Calamintha Miller. In: Tutin, T. G., Heywood, V. H., Burges, N. A., Moore, D. M., Valentine, D. H., Walters, S. M., Webb, D. A., (eds.), Flora Europaea 3, 163-167. Cambridge University Press, Cambridge.

BALDACCI, A., 1891: Cenni ad appunti intorno alla flora del Montenegro IV. Malpighia (Genova) 5, 61-81.

BALDACCI, A., 1892: Altra notizie intorno alla flora del Montenegro. Malpighia (Genova) $6,1-123$.

BALDACCI, A., 1894: Contributo alla conoscenza della flora dalmata, montenegrina, albanesa, epirota e greca. Nuovo Giornale Botanico Italiano (Nuova serie) 1, 90-103. 
BALDACCI, A., 1900: Contributo alla conoscenza della flora del confine montenegro-albanese. Memorie della Reale Accademia delle Scienze dell'Istituto di Bologna, $1-43$.

BALDACCI, A., 1901: Rivista della collezione botanica fatta nell 1897 nell'Albania settentrionale. Memorie della Reale Accademia delle Scienze dell'Istituto di Bologna 9, 513-553.

Blečić, V., Pulević, V., 1979: New data for the flora of Montenegro (In Serbian). Glasnik Republičkog Zavoda za Zaštitu Prirode i Prirodnjačkog Muzeja u Titogradu 12, 189_ 193.

BORNMÜLlER, J., 1926: Beiträge zur Flora Mazedoniens II. Botanische Jahrbücher für Systematik, Pflanzengeschichte und Pflanzengeographie 40, 1-125.

Bräuchler, C., Meimberg, H., Abele, T., Heubl, G., 2005: Polyphyly of the genus Micromeria Benth. (Lamiaceae) evidence from cpDNA sequence data. Taxon 54, 639-650.

Bräuchler, C., Ryding, O., Heubl, G., 2008: The genus Micromeria (Lamiaceae), a synoptical update. Willdenowia 38, 363-410.

Cha Ter, A. O., Guinea, E., 1972: Micromeria Bentham. In: Tutin, T. G., Heywood, V. H., Burges, N. A., Moore, D. M., Valentine, D. H., Walters, S. M., Webb, D. A., (eds.), Flora Europea 3, 167-170. Cambridge University Press, Cambridge.

Černjavski, P., GrebenščIKov, O., PAVlović, Z., 1949: Vegetation and flora of Skadar Lake area (In Serbian). Glasnik Prirodnjačkog Muzeja Srpske Zemlje, Serija BBiološke nauke 1-2, 5-91.

DAVIs, P. H., (ed.) 1982: Flora of Turkey and the east Aegean islands 7. University Press, Edinburgh.

Diklić, N., 1974: Micromeria Benth. In: Josifović, M., (ed.), Flora of Serbia (In Serbian) 6, 458-462. SANU, Belgrade.

EbeL, W., 1844: Zwölf Tage in Montenegro und ein Blick auf Dalmatien. Verlag von J. H. Bon, Königsberg.

Feráková, V., 1976: Lactuca L. In: Tutin, T. G., Heywood, V. H., Burges, N. A., Moore, D. M., Valentine, D. H., Walters, S. M., Webb, D. A., (eds.), Flora Europaea 4, 328-331. Cambridge University Press, Cambridge.

FERÁKOVÁ, V., 1977: The genus Lactuca L. in Europe. Komenský University Press, Bratislava.

Greuter, W., Burdet, H. M., Long, G., 1986: Med-Checklist 3. A critical inventory of vascular plants of the circum-mediterranean countries. Dicotyledones (Convolvulaceae-Labiatae). Genève et Berlin.

HAND, R., 2006: Supplementary notes to the flora of Cyprus. Wildenowia 36, 761-809.

HayeK, A., 1931: Prodromus florae peninsule balkanicae. Berlin-Dahlem: Verlag des Repertoriums 2, 488, 768.

JAMZAD, 2009: New species and new plant records of Lamiaceae from Iran. Iranian Journal of Botany 15, 51-56.

KiLIJAn, N., 2001: Lactuca stebbinsii (Lactucaceae, Compositae), a puzzling new species from Angola. Wildenowia 31, 71-78. 
Koopman, W. J. M., Guetta, E., Van de Wiel, C. C. M., Vosman, B., Van den Berg, R. G., 1998: Phylogenetic relationships among Lactuca (Asteraceae) species and related genera based on ITS-1 DNA sequences. American Journal of Botany 85, 1517-1530.

Lebeda, A., Doležalová, I., Kristková, E., Mieslerová, B., 2001: Biodiversity and ecogeography of wild Lactuca spp.in some European countries. Genetic Resources and Crop Evolution 48, 153-164.

Lebeda, A., Doležalová, I., FerÁkovÁ, V., Astley, D., 2004: Geographical Distribution of Wild Lactuca Species (Asteraceae, Lactucaceae). Botanica Review 70, 328-356.

MilanoviĆ, M., 1964: Geological composition and tectonics of the broader area of Rumija mountain in the coastal part of Montenegro (In Serbian). Geološki Zavod, Sarajevo.

PANČı́́, J. (1875): Elenchus plantarum vascularium quae aestate a.1873 in Crna Gora. In Typographia Status, Belgrade.

Petrović, D., 2005. A Contribution to knowledge of the Mountain Sutorman flora. Natura Montenegrina 4, 17 - 21.

Prather, L. A., Monfils, A. K., Posto, A. L., Williams, R. A., 2002: Monophyly and phylogeny of Monarda (Lamiaceae): Implications of sequence data from the internal transcribed spacer (ITS) region of nuclear ribosomal DNA. Systematic Botany 27, 127-137.

Pulević, V., 2005: Materials for the vascular flora of Montenegro: a supplement to »Conspectus Florae Montenegrinae « (J. Rohlena). Republic Institute for Nature Protection of Montenegro (Special editions, 2), Podgorica.

Rohlena, J., 1942: Conspectus florae Montenegrinae. Preslia 20-21, 1-506.

SoŠKA, T. H., 1939: Beitrag zur Kenntnis der schluchtemfloren von Südserbien. Bulletin de la Société Scientifique de Skoplje. Section des Sciences Naturelles 7, 35-58.

StebBins, G. L., 1937: Critical notes on Lactuca and related genera. Journal of Botany 75, $12-18$.

Stevanović, V., Bulić, Z. 1992: New data on chorology and phytocenology of the species Ramonda serbica Panč. (Gesneriaceae) in Montenegro. Glasnik Republičkog Zavoda za Zaštitu Prirode i Prirodnjačkog Muzeja u Titogradu 25, 7-16.

ŠIlić, Č., 1979: Monograph of the genera Satureja L., Calamintha Miller, Micromeria Bentham, Accinos Miller and Clinopodium L. in the flora of Yugoslavia. Zemaljski Muzej Bosne i Hercegovine, Sarajevo.

TAN, K, Mullaj, A. 2001: Berberidaceae. In: Greuter W., Raus, T. (Eds.), Med-Checklist Notulae. Wildenowia 31, 320.

TuISL, G., 1968: Der Verwandtschaftskreis der Gattung Lactuca L. im Iranischen Hochland und seinen Randgebieten. Annalen des Naturhistorischen Museums in Wien 72, 587-638.

Trusty, J. L., Olmstead, R. G., Bogler, D. J., Santos-Guerra, A., Francisco-Ortega, J., 2004: Using molecular data to test a biogeographic connection of the Macaronesian genus Bystropogon (Lamiaceae) to the New World: a case of conflicting phylogenies. Systematic Botany 29, 702-715.

Wagstaff, S. J., Olmstead, R. G., CAnTino, P. D., 1995: Parsimony analysis of cpDNA restriction site variation in subfamily Nepetoideae (Labiatae). American Journal of Botany $82,886-892$. 